游耕农民的地方性知识和可持续土地利用的挑战:

老挝北部流域管理项目的经验与教训

\title{
LOCAL KNOWLEDGE OF SWIDDEN FARMERS AND CHALLENGES FOR SUSTAINABLE LAND USE: LESSONS FROM A WATERSHED MANAGEMENT PROJECT IN NORTHERN LAOS
}

里见· 东 ${ }^{1}$ 日本科学促进会博士后研究员

Satomi HIGASHI ${ }^{1}$ Postdoctoral Research Fellow, Japan Society for the Promotion of Science

satomihgs@yahoo.co.jp.

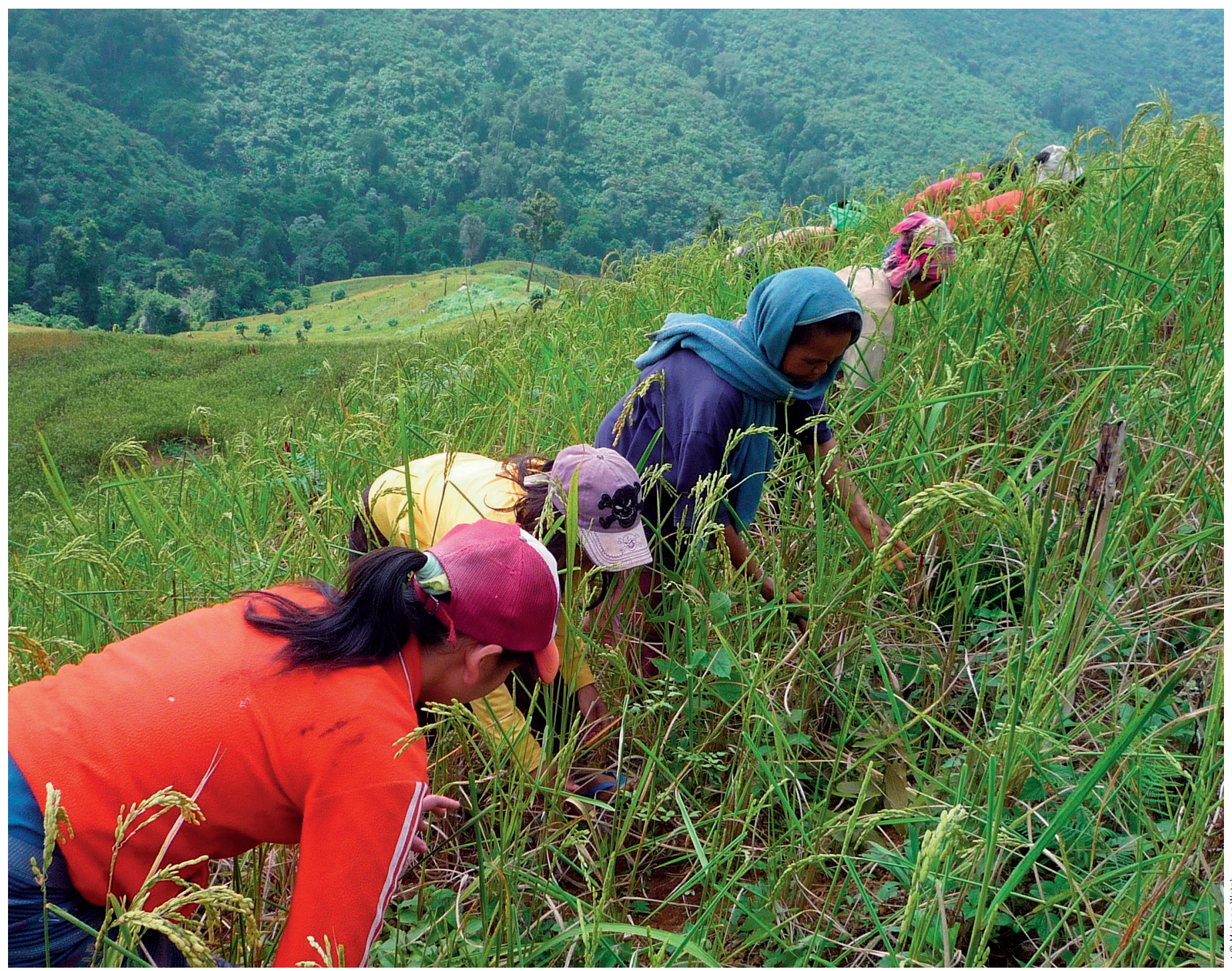


(1) 2005 2013年间, 里 见·东在老挝乌多姆赛 省负责社区流域管理项 目，并担任日本非政府 环境组织“泪公 环境组织“湄公河观 察”的老挝方项目负

(2) 克木族属于南亚语系盘 高棉语族中的一个族 群，大部分族人居住在 老挝北部。

1. From 2005 to 2013, Satomi Higashi was engaged in the Communitybased Watershed Management Project in Oudomxay Province, Lao PDR, as a Lao Program Director of Mekong Watch, a Japanese environmental NGO

在老挝乌多姆赛省北宾 区的高地上, 人们在稳 田里除草。

Weeding in upland rice fields, Pakbeng District, Oudomxay Province.
在老挝北部山村水稻丰收之时, 我曾询 问一位当地村民他们家来年会在哪里种植水 稻, 他回答说: “我还不知道。明年二月村 里会专门讨论这个问题。”由于当时对游耕 还所知甚少, 这一回答令我非常困惑: 村民 为什么连自己几个月后将在哪里种地都不知 道呢?

实际上, 游耕是一套完整的农业体系: 一部分的森林被清理、焚烧、短期耕种, 然 后休耕一段时间。几年后, 植被恢复到一定 水平, 这片土地才会被再次用作耕地。在老 挝，有25\%的农村人口采用游耕这种生产方 式 ${ }^{[1]}$ 。但据老挝农业与林业部调查统计, 涉 及游耕的土地面积和家庭数量正逐年降低: 从1996年的1 766 km² 和186 265户，减少

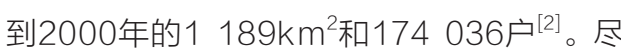
管如此, 游耕仍然是老挝、尤其是北部山区 最重要的食物生产方式之一。

\section{乌多姆赛省北宾区克木族人的土地利用}

老挝北部乌多姆赛省的北宾区山峦绵 亘, 生活在这里的大部分居民都是克木族 人 (2)。他们自古便以游耕、狩猎、捕捞和非 木材林产品采集等农业生产方式谋生。其生 活、文化和宗教均与游耕密不可分。
该地区的轮作周期通常为 7 9年。北宾 区的部分村庄不允许村民自主选择耕地, 而 是请村里备受尊敬的人, 比如长者或富有学 识的权威人士, 在每年二月前后依据休耕时 长、土地状况（如树木生长状况和土质）, 及其经验为村民选定地块, 随后再根据每户 可用劳动力的数量来分配耕地。这种土地利 用系统使得克木族人民每年收成稳定, 且能 够灵活应对人口波动等社会及环境变化。

\section{粮食安全与游耕}

克木族人游耕的主要作物是高地糯米。 仅在北宾区的一个村庄内, 当地村民就种植 了至少三种早熟品种、三种中熟品种和超过 12 种晚熟品种。在不同时期种植水稻或将 其采收期错开, 是规避慊收的良方。除旱稻 外, 克木族农民还在游耕耕地中整齐地栽种 了玉米、芋头、木薯、红薯、红辣椒、茄子、 南瓜、芝麻和豆类作物。然而, 据村中的老人 介绍, 用于游耕的农作物品种已有所减少。例 如, 传统用于酿酒的小米如今已少有种植。

用于游耕的土地在收获后的几年中保持 休耕。收获后的第一年, 地块上会长满等身 高的野草, 最终回归次生林的状态, 并生长 出竹笋和蘑菇等非木材林产品—它们也可
https://doi.org/10.15302/J-LAF-20180312 收稿时间 RECEIVED DATE / 2018-06-05 中图分类号 / S3, TU98

文献标识码/B
老挝地处东南亚大陆, 在其境内的许多地区, 游耕已成 为关平当地社区粮食安全以及宗教、文化寄托的重要生计之 一一对于老挝的高地地区尤为如此。

由于多项土地和森林管理政策，以及村庄迁移和合并计 划的推行, 老挝北部乌多姆赛省北宾区的社区居民进入森林 的权利受到限制, 因而不得不面对耕地资源短缺的问题。在 没有足够耕地的情况下, 当地农民开始以一种破坏性的方式 使用森林资源。

作为非政府环境组织的项目负责人，作者参与了一项基 于社区的流域管理项目，并克服重重挑战，找到了适于当地 社区土地利用的土地和森林管理体系。该非政府组织尝试采 用一种替代方案, 以使游耕农民的土地利用方式与官方土地 和森林管理体系并存互利。

\section{关键词}

游耕; 高地农民; 土地和森林管理政策; 老挝; 非政府组织

\section{ABSTRACT}

In Laos, located in mainland Southeast Asia, shifting cultivation has been one of the important means of livelihood, in terms of food security as well as religious and cultural anchorage, for local communities in a number of areas, especially in upland areas in the country.

In Pakbeng District, Oudomxay Province, northern Laos, due to the implementation of various land and forest management policies and a village relocation and consolidation program, local communities were restricted from access to the forests and faced a shortage of agricultural lands. After facing difficulties in securing sufficient lands, the local farmers used the forests in a destructive manner.

The author of this article was engaged with the Community-based Watershed Management Project, as a program director of an environmental NGO and tackled challenges to achieve a land and forest management system suitable for land use by local communities. The NGO attempted to apply an alternative approach to incorporate swidden farmers' land use system into official land and forest management institutions.

KEY WORDS

Shifting Cultivation; Upland Farmers; Land and Forest Management Policies; Laos; NGO

译张健陆小璇

TRANSLATED BY Angus ZHANG Xiaoxuan LU 
以被收割并食用。而后, 当植被恢复得足够 好时, 土地会再次被选作耕地。由于占据不 同地理位置、拥有各式场地条件, 游耕形成 的次生林成为了各种野生动植物的栖息地。 这些次生林为克木族村民提供了多种多样的 农产品, 用以支持他们的生活和生计一一它 们有时作为大米的替代品, 有时也成为创收 来源。在粮食短缺的紧急情况下或对于贫困 家庭来说, 从次生林采集的根茎类作物（如 山药、芋头和木薯) 是优质的粮食替代品 ${ }^{[3]}$ 。 事实上, 有些植物甚至只在次生林中生长。 我们需要认识到, 在游耕中休耕的土地仍具 生产力, 并且能够支持高地村民的生活。

\section{政府土地和森林管理政策对游耕土地利 用的影响}

尽管在游耕土地上进行水稻生产仍然是 老挝最重要的生计之一, 但老挝政府认为, 游耕是导致森林砍伐的主要原因, 并于20世 纪80年代中期通过了《根除游耕政策》。为 推行这一政策, 老挝自1996年起一直坚持 实施《土地和森林分配方案》( LFA)。该 方案以保护自然环境、阻止游耕、鼓励村民 种植经济作物以增加当地居民收入为目标, 实施了重新划定村庄边界、为村民分配新 的耕地, 以及圈定村庄内可用森林范围等举 措。LFA的确促进了一些地区的森林保护和 驻地农业的发展, 但在其他地区, 土地和森
林利用情况并未得到实质性的改善, 甚至还 造成了森林资源的枯竭。而在以老挝北部为 代表的那些以游耕为主要生计的地区, 该方 案亦加剧了当地的贫困程度。

\section{寻求替代方案所面临的挑战：基于社区 的北宾区流域管理}

老挝的土地和森林正迅速发展演变。 仅通过停止推行LFA和恢复 “传统的”土地 利用方式，并不足以捍卫村民们在土地、森 林及其可持续管理方面的权利。随着当地人 口的增长和融入全球市场经济步伐的加快, 老挝的土地一一包括农业用地一一正日益稀 缺, 农地短缺问题不容小视。当现有土地储 量无法满足日益增长的村庄人口的需求时， 村民可能会开始开脣以往受保护的土地, 如 水源地或河岸用地。这无疑会增加环境的负 担。此外, 开发项目、工业种植园和经济作 物种植也正在老挝农村地区快速扩张。为使 村民权利免受外国公司和开发项目影响，确 保社区生计的可持续发展, 赋予村民自行管 理森林的权力, 我们需要明确村庄边界, 并 对村民的土地权利施以法律保障。

2005 2013年间，日本非政府环境组 织 “涺公河观察”与老挝国立大学林业系 及北宾地区林业局合作, 开展了一项行动研 究, 并针对流域森林管理和利用提供咨询服 务。该项目包括：1) 为制定老挝土地和森

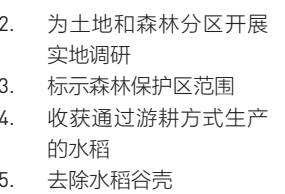

2. Survey preparing for land and forest demarcation

3. Marking protected forests

4. Harvesting swidden rice 5. Removing rice husks
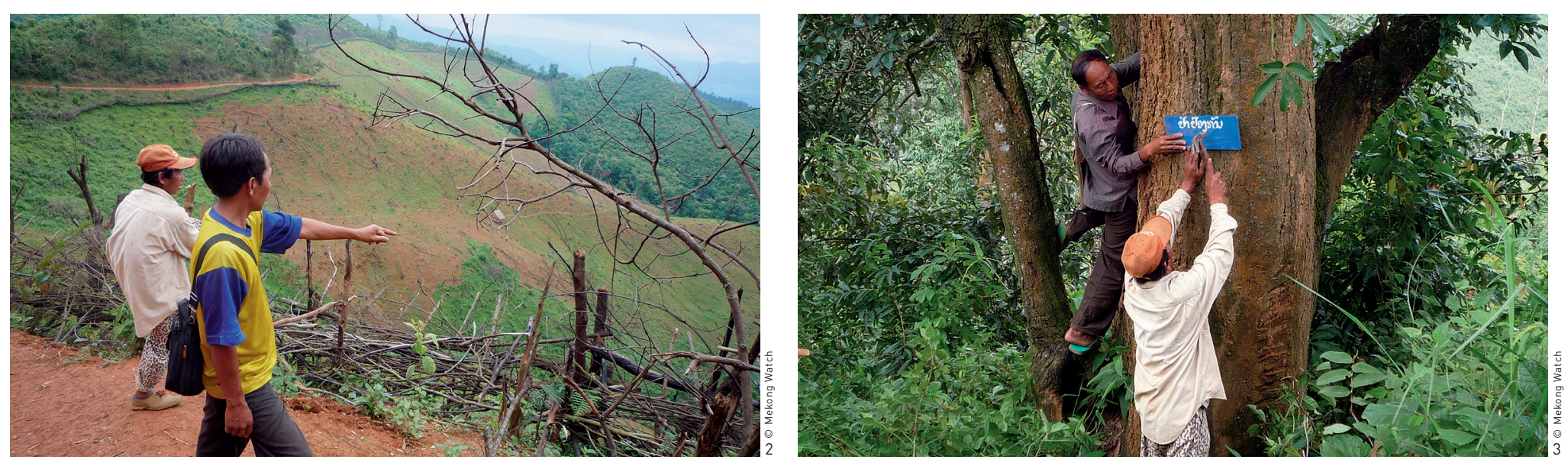
林政策的官员提供建议；2）对流域森林附 近村民的土地和森林利用情况进行研究;

3) 对流域森林进行环境监测；4）建立并支 持运营流域森林管理委员会；5）协助5座未 考虑实际土地利用情况而实施了LFA的村庄 进行土地和森林的重新分类； 6 ) 就环境问 题为村民提供培训。

在本项目开展以前, 村民和官员们从 未有机会聚在一起讨论地和森林的利用问 题。而如今, 通过这个由流域内 8 个村庄的 代表和地方官员组成的流域管理委员会, 他 们可以就森林保护和土地利用的年度计划进 行磋商, 并着手处理可能发生在村庄之间或 村庄与行政办公室之间的那些与土地相关的 问题。现在, 如果一个村庄需要在流域森林 中获取游耕土地, 其可以向委员会提交土地 使用计划——在委员会成立前, 在流域森林 中申请游耕土地的诉求被完全禁止, 甚至没 有任何途径提出这样的请求。如今, 在委员 会制定的规则范围内, 如果其他村庄和地区 在会议上批准土地使用计划, 申请方就可以 在流域森林中的部分区域开展游耕。只要遵 循村庄和地区制定的保护河流和水源地附近 森林的原则, 村民们便不再需要非法占用土 地进行游耕。

\section{新的挑战与游耕农民的未来}

老挝政府一直在推动本国一一特别是 施行游耕的地区一的农业向经济作物种植 转变。然而, 他们却并未将市场价格波动、 负面环境影响等相关风险恰当地传达给种植 者。在不解决这些风险的前提下快速转向种 植经济作物, 无疑会对当地村民的粮食安全 造成威胁。另一方面, 随着村民对现金收入 需求的增加, 经济作物种植范围也正迅速扩 张。我们应当在平衡经济创收与村民粮食安 全的基础上, 从地区和乡村两个层面对经济 作物的引进进行严格规划。无论是继续游耕 还是采用其他土地利用方式, 重要的是, 居 民都可以根据充足的信息和长远的愿景, 选 择他们认为最适合自己和当地需求的土地利 用方式。LAF
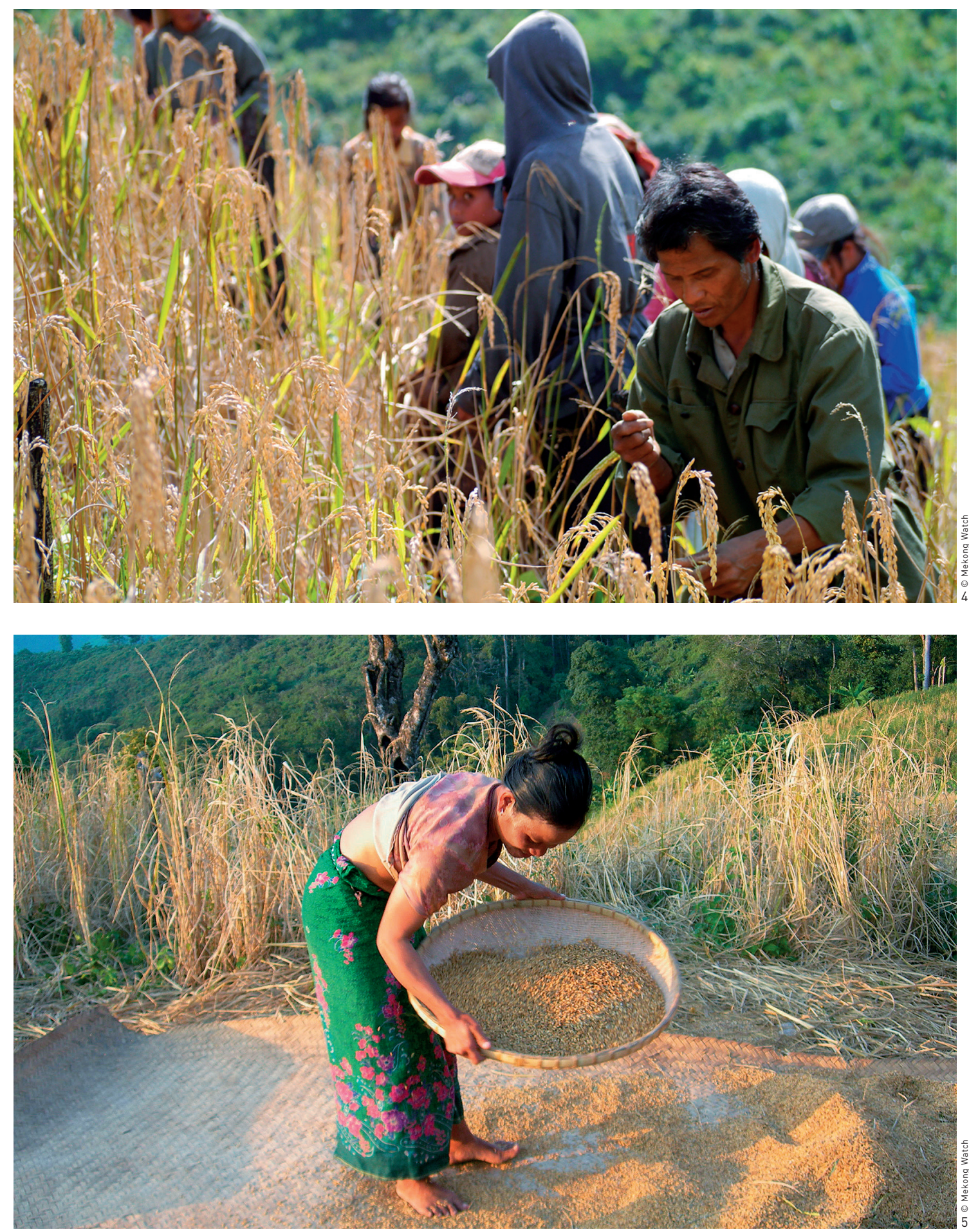


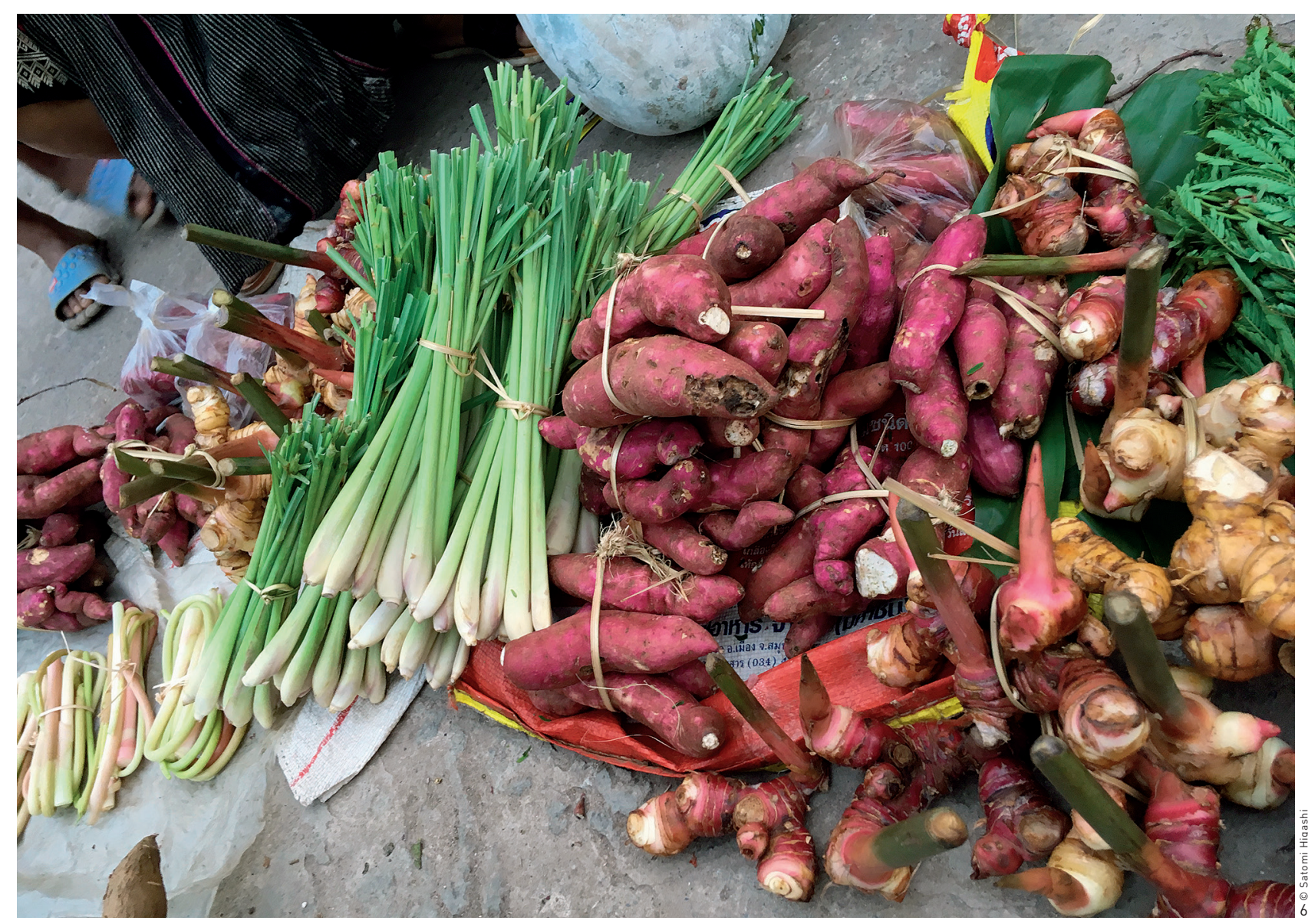

(2) Kmhmu' is an ethnic group belonging to the Mon-Khmer language sub-branch of the Austro-Asiatic language family, the majority of whom live in northern Laos.

When I asked a villager of a mountainous village in northern Laos in the harvest season where his family would plant rice next year, he answered, "I don't know yet. We will discuss it in the village in February." I was not familiar with shifting cultivation at the time, so his answer confused me. Why did not villagers know where they were going to cultivate just a few months after?

Shifting cultivation is an agricultural system in which sections of forest are cleared, burned, cultivated for a short period, and then abandoned for a certain period of time. After the vegetation returns to a suitable level several years after the harvest, the field will be selected again for farmland. In Laos, $25 \%$ of the rural population were involved in shifting cultivation $^{[1]}$. According to the Ministry of Agriculture and Forestry, the area and number of households involved in shifting cultivation have gradually decreased from 176,605 hectares and 186,265 households in 1996 to 118,900 hectares and 174,036 households in $2000^{[2]}$. However, it is still a crucial method for producing food, particularly in the mountainous areas in the North.

\section{Kmhmu' People's Land Use in Pakbeng District, Oudomxay Province}

Pakbeng District, Oudomxay Province in northern Laos is mountainous and most of the residents are $\mathrm{Kmhmu}^{\cdot{ }^{2}}$. Traditionally, Kmhmu' people have made their living from agricultural production through shifting cultivation, hunting, fishing, and non-timber forest product (NTFP) collection. Their life, culture, and religion have close connections with shifting cultivation.

Shifting cultivation is typically conducted in seven to nine-year cycles in this area. In some villages in Pakbeng, instead of allowing individuals to choose their swidden fields, villagers asked respected figures in the village, such as elders and knowledgeable authorities to select plots of land for cultivation around February every year. Selection was based on how long land was left fallow, condition of the land, e.g., the size of trees and the soil quality, and the respected figures' experience. Once plots were chosen, village authorities distributed them to each household according to the 

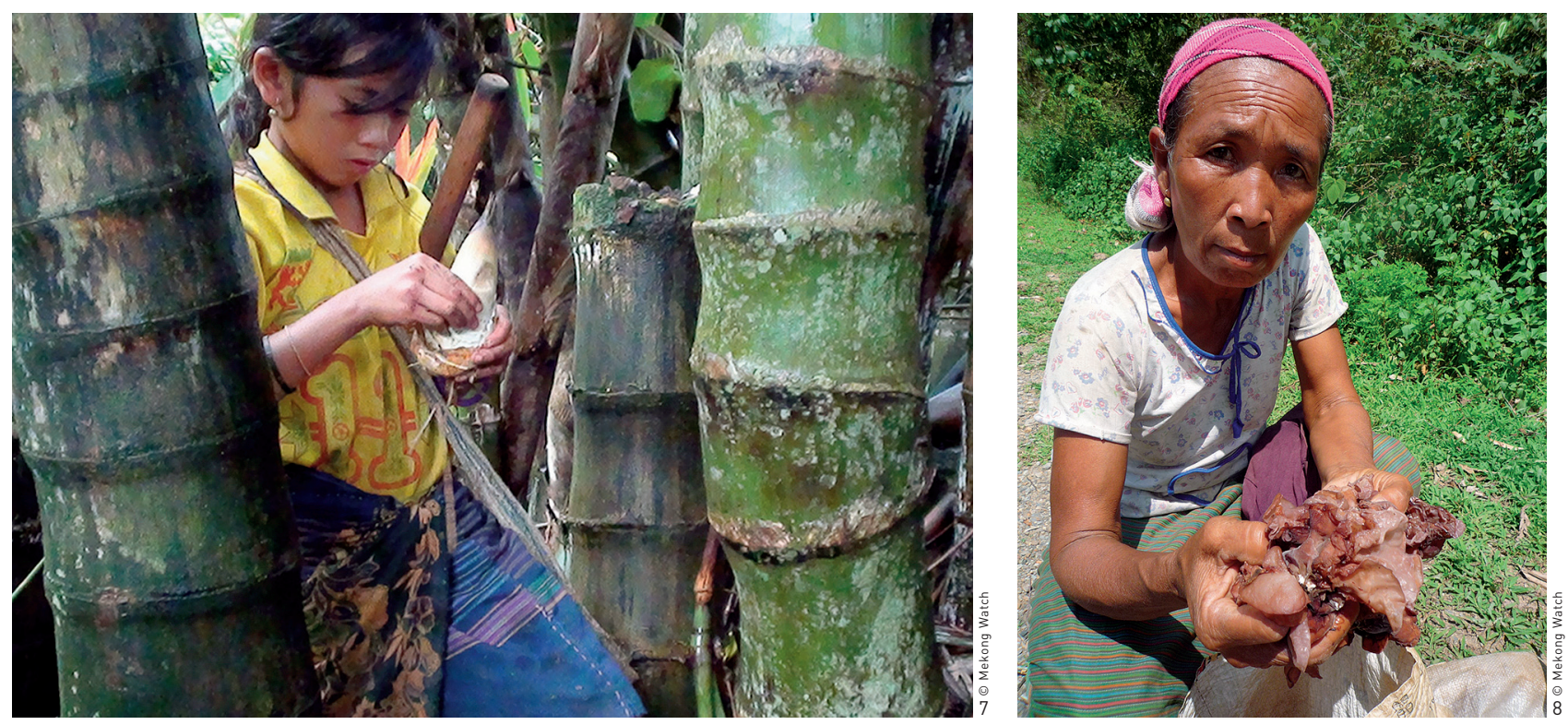

workforce available in the household. This system of land use made it possible for the $\mathrm{Kmhmu}$ ' to produce a steady harvest every year and to adjust flexibly to social and environmental changes such as population fluctuations.

\section{Food Security and Shifting Cultivation}

The main shifting cultivation crop planted by the Kmhmu' is upland glutinous rice. In one village in Pakbeng, at least three varieties of the early-ripening, three varieties of the mid-season and more than 12 varieties of the late-growing rice were in use. Planting rice at different or staggered harvest periods was a way to hedge against the risk of poor harvests. Along with upland rice, an array of crops is planted by Kmhmu' villagers on shifting cultivation fields.

They include corn, taro, cassava, sweet potato, chili, eggplant, pumpkin, sesame, and beans. According to elderly villagers, however, the number of crop varieties has decreased. For example, millet, which is traditionally used for making alcohol, is now rarely planted.
When land is used for shifting cultivation, it is left fallow for some years after crops are harvested. After a year, the land becomes home to grass as tall as a person, and ultimately reverts to secondary forest, producing NTFPs such as bamboo shoots and mushrooms. These NTFPs can also be harvested and eaten. Later, when vegetation has regenerated to a sufficient degree, the land is selected for cultivation again. Secondary forests resulting from shifting cultivation become home to a variety of wild flora and fauna, depending on the location and conditions. Secondary forests support the lives and livelihoods of Kmhmu' villagers by offering various products. These can sometimes serve as substitutes for rice and can also be used as a means of generating cash income. Roots and tubers collected from secondary forest (e.g., yam, taro, and cassava) are considered good substitutes during emergencies or for poorer households ${ }^{[3]}$. Some plants grow only in secondary forests. It is important to understand that fallow land in shifting cultivation is still productive and supports the lives of upland farmers.
6. 从高地稻田中收获的作 物被运送到当地市场上 售卖。
7. 从次生林中收获的竹算 8. 从次生林中采集的蘑菇 9. 村民们用竹子编织日常 生活所需的竹篮

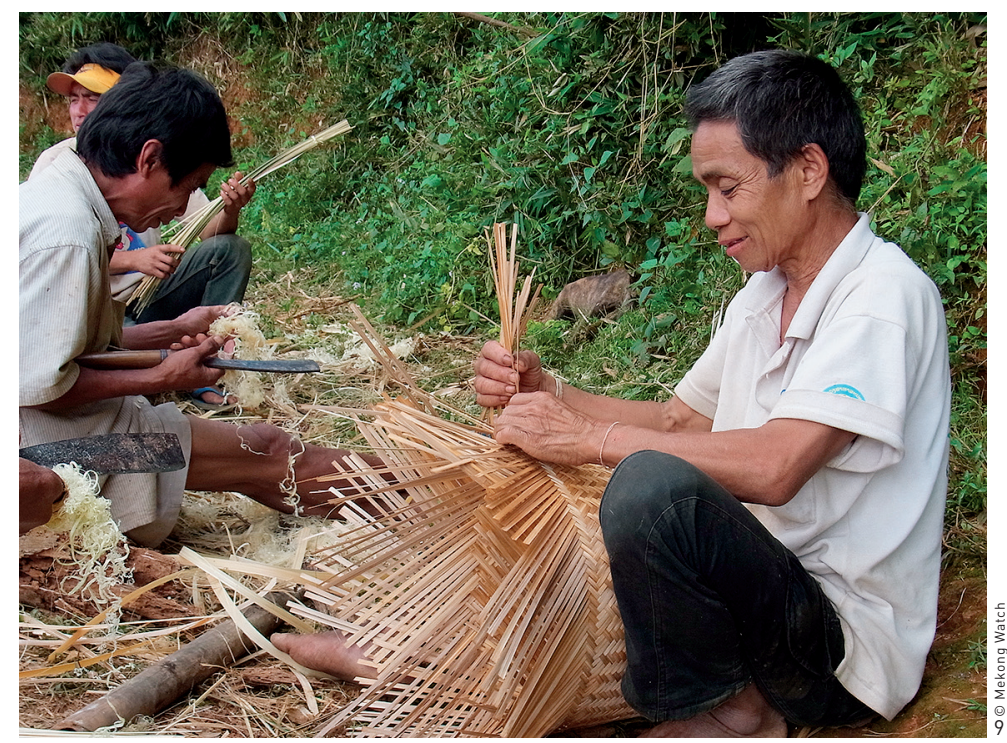




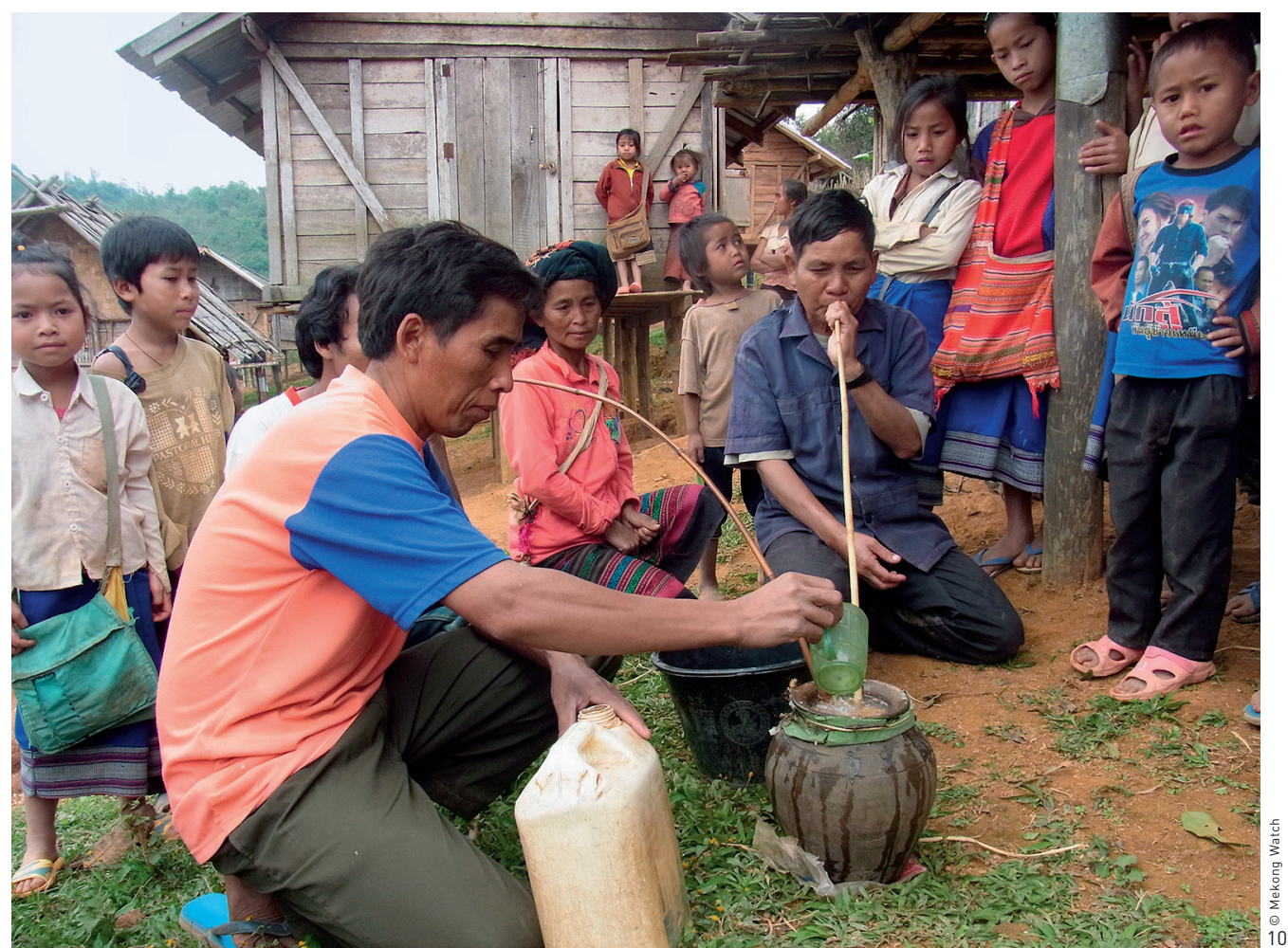

\section{Impacts of the Government's Land and Forest Management Policies on Shifting Cultivators' Land Use}

Although rice production in swiddens remains one of the most important livelihoods in Laos, the Lao government has deemed shifting cultivation a major cause of deforestation and adopted the Shifting Cultivation Eradication Policy from the mid-1980s. To promote the policy, the Land and Forest Allocation Program (LFA) has been implemented throughout Laos since 1996. The stated goals of the program are preserving the natural environment, discouraging shifting cultivation, and promoting cash-crop farming among residents to increase local people's income. Project activities such as the redrawing of village boundaries, allocating new farmland to people, and establishing forest-use zoning within villages are being implemented.
It is true that LFA has contributed to forest preservation and the promotion of stationary agriculture in some areas. However, in other areas, LFA brought no practical improvements in land and forest use and even caused the exhaustion of forest resources. LFA has been held liable for aggravating poverty especially in northern Laos, where shifting cultivation is the main livelihood of the local people.

\section{Challenges in Seeking Alternative Approaches: Community-Based Watershed Management in Pakbeng}

Land and forests are going through rapid changes in Laos. A mere suspension of LFA and recovery of "traditional" land use will not be enough to defend villagers' rights to land and forests and to their sustainable management. As the population increases and integration into the global market economy accelerates, land, including agricultural land, is becoming increasingly scarce in Laos. Shortage of agricultural land is also becoming a serious issue. When the population of a village grows and more land is needed, villagers may start cultivating traditionally protected areas such as areas around water sources or river banks. The cultivation of protected areas will increase the burden on the environment. In addition to these changes, development projects, industrial plantations, and cash crop cultivation are expanding rapidly in rural parts of Laos. In order to protect villagers' rights from foreign companies and development projects, to ensure sustainable livelihoods for communities, and to allow villagers to manage forests by themselves, village borders need to be determined and villagers' rights over land must be supported by law.

Mekong Watch, a Japanese environmental NGO, conducted action 
10.在克木族丰收庆典上吸 食米酒

11. 拍摄纪录片以记录游耕 生产方式和高地农民的 生活

12. 针对村中土地利用相关 问题开展的研讨会
10. Drinking lao hai (rice wine) in a Kmhmu harvest ritual.

11. Shooting a documentary film on shifting cultivation and upland farmers' life

12. A workshop to discuss issues related to land use in villages
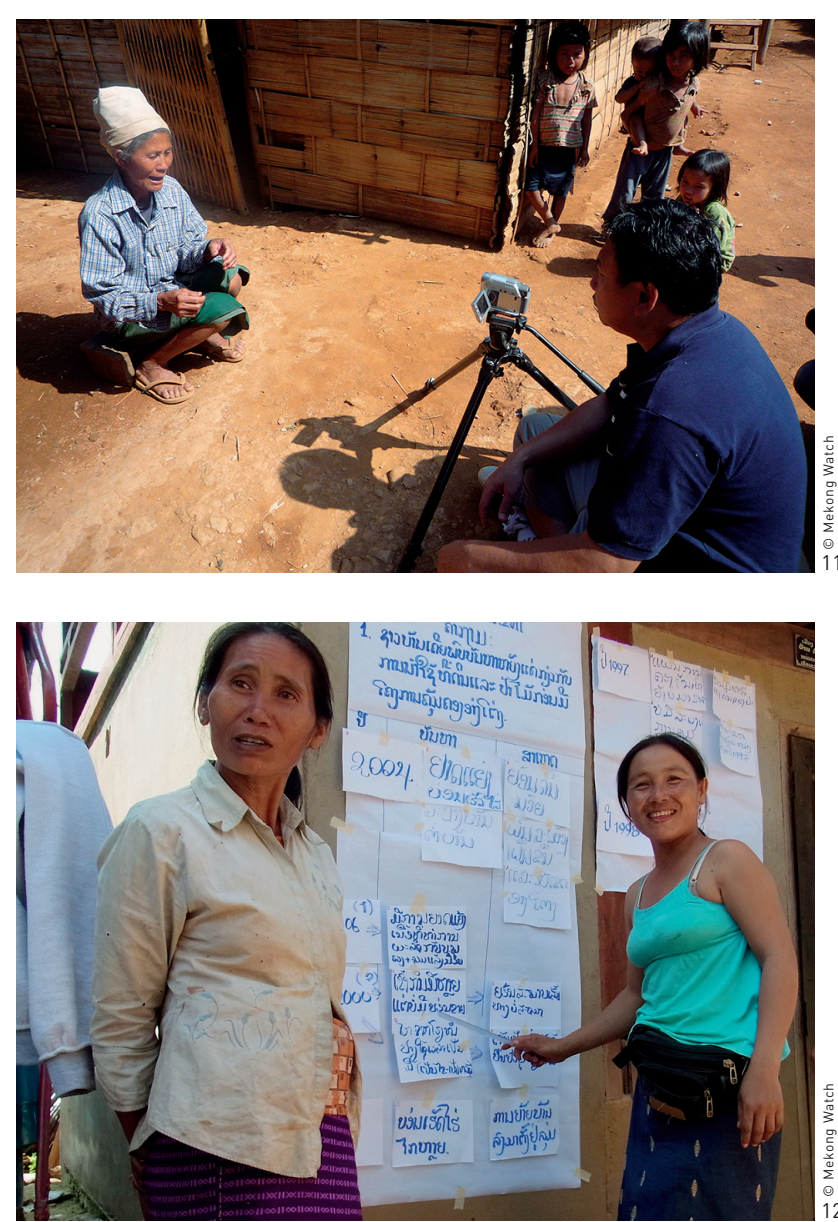

research and provided advice on management and use of watershed forests from 2005 to 2013 in cooperation with the Forestry Department of Laos National University and the Pakbeng District Forestry Office. The project included: 1) advising local officials on land and forest policy in Laos, 2) conducting research on villagers' land and forest use near watershed forests, 3) environmental monitoring of watershed forests, 4) setting up and supporting the watershed forests management committee, 5) providing assistance to reclassify land and forest in five villages where the LFA had been implemented without much consideration for the actual land use, and 6) providing training to villagers on environmental issues.

Until the project began, there was no opportunity for villagers and officials to discuss land and forest use. Through the watershed management committee, which is composed of representatives from eight villages in the watershed area and local officials, they can now consult with each other on annual plans for forest preservation and land use, and deal with land-related troubles which may occur between villages or between villages and administrative offices. If a village needs to secure swiddens in watershed forests, it can now submit a land use plan to the committee. Swiddens in watershed forests used to be banned without exception and there was no avenue for making such a request before the committee was set up. It is now possible to cultivate swiddens in some parts of watershed forests if other villages and districts approve the land use plan at the committee meeting with reference to the rules enacted by the committee. Villagers no longer need to make swiddens illegally as long as they follow the rules set by villages and the district for preservation of forests near rivers and water sources.

\section{New Challenges and the Future of Shifting Cultivators}

The Lao government has been promoting a shift to cash crop cultivation, especially among local communities engaged in shifting cultivation. Risk-related information such as fluctuations in market prices and negative environmental impacts, however, is not properly communicated to growers. A rapid shift towards cashcrop cultivation without addressing these risks, threatens local people's food security. On the other hand, as villagers' demands for cash income increase, cash crop cultivation also expands. The introduction of cash crops should have been rigorously designed both at the district and village levels, based on careful consideration about how to achieve a balance between income generation and villagers' food security. Whether shifting cultivation is continued or other land use methods are adopted, it is important that residents can select methods of land use that they deem to be most suitable for themselves and local needs, based on sufficient information and long-term prospects. LAF

REFERENCES

[1] Kitamura, N. (2003). Forest Policy Development in Laos. In M. Inoue, \& H. Isozaki (Eds.), People and Forest - Policy and Local Reality in Southeast Asia, the Russian Far East. and Japan (pp. 113-126). Dordrecht: Kluwer Academic Publishers.

[2] Higashi, S. (2013). Toward Community-Based Forest Management: Working with Local People to Preserve Watershed Forests in Northern Laos. In T. Doi, \& M. C. Onizuka (Eds.), Nature and Our Future: The Mekong Basin and Japan. Tokyo: Mekong Watch.

[3] Higashi, S. (2015). An Alternative Approach to Land and Forest Management in Northern Lao PDR. In C. Erni (Ed.), Shifting Cultivation, Livelihood and Food Security: New and old Challenges for Indigenous Peoples in Asia (pp. 253-290) Retrieved from http://www.fao.org/3/a-i4580e.pdf

[4] Ministry of Agriculture and Forestry, Vientiane. (1999). The Government's strategic vision for the agricultural sector.

[5] Stoeber, S., Sisomphone, E., \& Han, C. (2013). Women, Food and Land: Understanding the Impact of Gender on Nutrition, Food Security and Community Resilience in Lao PDR. Retrieved from https://www.care.org.au/wp-content/ uploads/2015/02/Women-Food-and-Land.pdf 